\title{
MUSEUM KAMBANG PUTIH TUBAN SEBAGAI SUMBER BELAJAR TENTANG TOLERANSI ANTAR UMAT HINDU, BUDHA, DAN ISLAM MASA MAJAPAHIT
}

\author{
Gargarisna Diputra \\ UNIVERSITAS PGRI RONGGOLAWE \\ gargarisna4251@gmail.com
}

\begin{abstract}
ABSTRAK
Salah satu obbjek wisata di daerah tuban yang menjadi andalan adalah Moseum Kambang Putih,Museum Kambang Putih terletak di jantung kota Tuban satu-satunya museum di kota Tuban, sangat strategis dan berdekatan dengan objek wisata lainnya, seperti; Masjid Agung Tuban, Makam Sunan Bonang, Pantai Boom, dan Klenteng Wan I. Museum ini menyimpan banyak warisan budaya, seperti benda-benda yang ditemukan di wilayah Kabupaten Tuban (Mashari, 2012). Museum Kambang Putih berada di kompleks alun-alun kota Tuban, tepatnya di sebelah barat Kantor Bupati Tuban. Berdekatan dengan kawasan wisata religi makam Sunan Bonang dan Masjid Agung Tuban. Museum yang buka setiap hari Senin Minggu ini merupakan pindahan dari museum Kambang Putih lama yang sebelumnya berada di kompleks Pendapa Kabupaten Tuban (Agung, 2012). Sewaktu berada di Kompleks Pendopo Krida Museum Kambang Putih sepi dari pengunjung karena letaknya yang jauh dari keramaian.

Kata museum merupakan reduplikasi dari kata yunani klasik Museon, yaitu bangunan suci sebagai pemujaan kepada Sembilan dewa seni dan ilmu pengetahuan Yunani kuno. Sedangkan pengertian museum sesuai dengan Peraturan Pemerintah nomor 19 tahun 1995, Museum adalah lembaga perawatan, penyimpanan, pengamanan, dan pemanfatan benda-benda bukti materiil hasil budaya manusia serta alam dan lingkungannya guna menunjang upaya perlindungan dan pelestarian kekayaan budaya bangsa. Dengan demikian museum terbuka untuk umum, khususnya untuk tujuan pendidikan dan rekreasi (Dinas Kebudayaan dan Pariwisata Provinsi Jatim, 2010:3). Dalam dunia pendidikan museum bisa dijadikan sumber dan media belajar terutama mata pelajaran sejarah
\end{abstract}

Kata Kunci: Museum Kambang Putih, koleksi museum, Pegawai 


\section{PENDAHULUAN}

Latar belakang karya tulis ini adalah sektor pariwisata sebagai kegiatan perekonomian telah menjadi andalan disetiap daerah dan prioritas pembangunan dalam sebuah negara, berlebih bagi Negara kita yang notabenya sebagai Negara yang berkembang. Indonesia memiliki potensi wilayah yang luas dengan adanya daya Tarik wisata cukup besar, banyaknya keindahan alam, aneka warisan sejarah busaya dan kehidupan masyarakatnya. Untuk meningkatkan peran kepariwisataan, sangat terkait antara barang berupa objek wisata sendiri yang dapat dijual dengan sarana dan prasarana yang mendukungnya yang terkait dalam industry pariwisata. Usaha mengembangkan sesuatu daerah tujuan tujuan wisata harus memperhatikan berbagai faktor yang berpengaruh terhadap keberadaan suatu daerah tujuan wiasata

Salah satu obbjek wisata di daerah tuban yang menjadi andalan adalah Moseum Kambang Putih,Museum Kambang Putih terletak di jantung kota Tuban satu-satunya museum di kota Tuban, sangat strategis dan berdekatan dengan objek wisata lainnya, seperti;
Masjid Agung Tuban, Makam Sunan Bonang, Pantai Boom, dan Klenteng Wan I. Museum ini menyimpan banyak warisan budaya, seperti benda-benda yang ditemukan di wilayah Kabupaten Tuban (Mashari, 2012). Museum Kambang Putih berada di kompleks alun-alun kota Tuban, tepatnya di sebelah barat Kantor Bupati Tuban. Berdekatan dengan kawasan wisata religi makam Sunan Bonang dan Masjid Agung Tuban. Museum yang buka setiap hari Senin Minggu ini merupakan pindahan dari museum Kambang Putih lama yang sebelumnya berada di kompleks Pendapa Kabupaten Tuban (Agung, 2012). Sewaktu berada di Kompleks Pendopo Krida Museum Kambang Putih sepi dari pengunjung karena letaknya yang jauh dari keramaian.

Kata museum merupakan reduplikasi dari kata yunani klasik Museon, yaitu bangunan suci sebagai pemujaan kepada Sembilan dewa seni dan ilmu pengetahuan Yunani kuno. Sedangkan pengertian museum sesuai dengan Peraturan Pemerintah nomor 19 tahun 1995, Museum adalah lembaga perawatan, penyimpanan, pengamanan, dan pemanfatan benda-benda bukti 
materiil hasil budaya manusia serta alam dan lingkungannya guna menunjang upaya perlindungan dan pelestarian kekayaan budaya bangsa. Dengan demikian museum terbuka untuk umum, khususnya untuk tujuan pendidikan dan rekreasi (Dinas Kebudayaan dan Pariwisata Provinsi Jatim, 2010:3). Dalam dunia pendidikan museum bisa dijadikan sumber dan media belajar terutama mata pelajaran sejarah

Maka dari itu penulis mengangkat museum kambang putih ini untuk memajukan sektor pariwisata. Khususnya pariwisata sejarah di daerah Tuban dan memperkenalkan sejarah kota Tuban kepada generasi muda agar lebih menghargai keberagaman budaya dan sejarah Kota Tuban dan ingin menunjukkan kepada dunia bahwa kota Tuban memiliki potensi pariwisata

Rumusan Masalah dari karya tulis ini adalah: (1) Bagaimana pengelolan Museum Kambang Putih? (2) Bagaimana pengunjung Museum Kambang Putih? (3) Bagaimanakah koleksi Museum Kambang Putih?

\section{METODE PENELITIAN}

Metode penelitian yang digunakan adalah studi literatur, observasi lapangan dan wawancara.

\section{PEMBAHASAN}

Dengan perkembangan museum muncul berbagai teori tentang pengertian museum. Beberapa pengertian museum :

[वMuseum adalah Sebuah lembaga yang bersifat tetap, tidak mencari keuntungan, melayani masyarakat dan pengembangannya terbuka untuk umum, yang memperoleh, merawat, menghubungkan dan memamerkan, untuk tujuan pendidikan, penelitian dan kesenangan, barang-barang pembuktian manusia dan lingkungannya. (International Council of Museum)

पMuseum adalah lembaga, tempat penyimpanan, perawatan, pengamanan, dan pemanfaatan benda-benda bukti materiil hasil budaya manusia serta alam dan lingkungannya guna menunjang upaya perlindungan dan pelestarian kekayaan budaya bangsa. (Peraturan Pemerintah No. 19 Tahun 1995 Pasal 1 ayat (1))

[Museum adalah tempat untuk mengumpulkan, menyimpan, merawat melestarikan, mengkaji, mengkomunikasikan bukti material hasil budaya manusia, alam dan lingkungannya (Amir Sutaarga, 1995:1.)

Dari beberapa pengertian tentang museum diatas dapat disimpulkan bahwa museum adalah suatu lembaga yang berupa bangunan atau tempat yang 
berfungsi sebagai tempat mengumpulkan, menyimpan, merawat melestarikan, mengkaji, mengkomunikasikan bukti material hasil budaya manusia, alam dan lingkungannya, yang bermanfaat bagi kehidupan sehari-hari (edukasi,rekreasi,dan konservasi).

Kepala UPTD Museum Kambang Putih secara periode terjadi pergantian posisi. Pergantian kepemimpinan membuat terjadi perubahan dalam kebijakan. Karakteristik kepemimpinan mempengaruhi terhadap perkembangan dari Museum Kambang Putih itu sendiri. Semakin professional kepala UPTD Museum Kambang Putih maka akan terjadi perkembangan yang pesat bagi Museum Kambang Putih. Sewaktu dikepalai oleh Supriyadi, S.Pd, perkembangan Museum Kambang Putih berjalan stagnan dari tahun ke tahun tidak terlihat adanya inovasi yang baru. Museum Kambang Putih agak sepi pengunjung, hal ini dikarenakan pada saat masuk dikenakan biaya masuk sukarela.

Pada era Dra. Santi Puji Rahayu biaya masuk sukarela dari Museum Kambang Putih ditiadakan. Dra. Santi Puji Rahayu secara professional mengelola Museum Kambang Putih, hal ini terlihat dari setiap kebijakan yang dikeluarkan. Mulai dari mengubah warna cat Museum Kambang
Putih dari putih menjadi orange yang terlihat lebih mencolok, mengadakan renovasibangunan termasuk atap dibuat ornamen motif batik pakaian tenun gedog dengan pengajuan dana kepada pemkab Tuban aktif, mengikuti berbagai kegiatan pameran yang diadakan oleh pemerintah propinsi maupun daerah guna memperkenalkan Museum Kambang Putih kepada masyarakat umum. Museum Kambang Putih juga memiliki arkeolog yang bernama Rony Firman Firdaus, SS yang membantu dalam pengelolaan Museum Kambang Putih.

Jumlah pegawai Museum Kambang Putih terdapat 9 orang. Latar belakang pendidikan dari pegawai Museum Kambang Putih antara lain: S1 IImu Sejarah Unej, S1 Arkeologi Udayana, S1 Sarjana Olahraga Unesa,S1 Administrasi dan sisanya memiliki ijasah SMA. Sumber Daya Manusia juga merupakan salah satu faktor dari baiknya pelayanan Museum Kambang Putih kepada msyarakat umum. Pada bulan November-Desember 2014, pihak pengelola Museum Kambang Putih melakukan renovasi \& pergantian, melengkapi sarana dan prasarana Museum Kambang Putih, hal ini dilakukan dengan bantuan dari dana daerah (PAK \& DPA - APBD). Sarana dan prasarana yang ditambah mulai dari pemasangan kamera 
CCTV, penambahan tempat penyimpanan, perluasan ruangan dalam, penambahan koleksi sampai dengan renovasi gedung dan pencahayaan.Pada tanggal 19 Desember 2014 di dalam radar Tuban (Jawa Pos) disebutkan "Plafon Berhias Batik Gedok" membuat tampilan langit-langit Museum Kambang Putih menjadi lebih khas. Motif batik gedok khas Tuban tidak sekedar hiasan, namun lebih mengenalkan pengunjung pada kekayaan budaya.

Pengunjung Museum Kambang Putih juga terus mengalami peningkatan, semenjak direnovasi tahun 2013 pengunjung dari kalangan umum, dan pendidikan. Data pengunjung Museum Kambang Putih diantaranya (Grup Fb Museum Kambang Putih, 2014) : 30-092014 Madrasah Aliyah Ash-Shomadiyah Tuban, 29-11-2014 SMP Al-Amin, Tunggul, Lamongan, Baby Care - Baby School - Kindergarten Full Day, SMART STUDENT CENTER (S2C), Jl. KH. Ahmad Dahlan No.70, Lamongan, Phone: 03226746447, 29-12-2014 Mencari potensi wisata Tuban dengan pembuatan vidio oleh komunitas Timur Bubar Production di Museum Kambang Putih, 2910-2014 Fam Tour Finalis Pemilihan Duta Wisata "CUNG DAN NDHUK" Kabupaten Tuban 2014 di Museum Kambang Putih,
24-09-2014 Kunjungan MGMP IPS SMP/MTs Gugus 02-Tuban, ke Museum Kambang Putih.

Pendataan Daftar Inventaris Museum Kambang Putih dilakukan sebanyak tiga kali. Inventaris pertama dilakukan pada tahun 1992-1993 meliputi koleksi keramik dan koleksi pra sejarah. Inventaris kedua dilakukan pada tahun 2003 terkait dengan koleksi etnografi dan koleksi Arkeologi. Dan pendataan terakhir dilakukan pada tahun 2012 meliputi keseluruhan Koleksi Museum Kambang Putih. Pendataan pada tahun 1992-1993 dan 2003 kurang dilakukan secara profesional karena banyak data yang tidak sesuai antara keterangan di Data Invetaris dengan sumber buku asli. Hal ini diakui oleh Arkeologi Museum, Rony Firman Firdauz, SS bahwa pendataan koleksi pada tahun 2012 banyak keterangan yang berbeda dengan sumber lain. Berdasarkan data inventarisasi Museum Kambang Putih bulan desember tahun 2012 koleksi Museum Kambang Putih dikategorikan menjadi 13 kategori ruang. 13 kategori dapat dilihat sebagai berikut:

- Prasejarah dan naskah kuno (fitrin atas)

a. Stegodon gajah (tulang paha, rahang bawah, tulang paha, 
Femur bagian engsel tulang paha, gading)

b. Fosil (tulang manusia, tanduk kerbau, tulang ekor, kulit kerang, kulit keong, cula badak, kayu)

c. Kapak persegi (cangkul, kapak persegi, belicung, beliung)

d. Perunggu (nekara kecil, kapak corong, mata tombak, pasu, wadah perunggu, mangkok. Bejana, darpana (cermin), boning perunggu)

e. Wadah perunggu (takaran, pasu, nampan, wadah)

f. Nekara (gajah, nekara, candrasah)

g. Naskah kuno (naskah pedalangan wayang purwa (jilid xxiv), naskah perhitungan tahun dan bulan, serat sekar macapat, kitab berhuruf jawa (bab hukum), naskah kitho mangko, kitab pegon).

h. Fosil kerang (fosil kerang, abjad kuno pertengahan, foto prasasti kambang putih, foto kehidupan prasejarah)

- Arkeologi (klasik Hindu Budha)

a. Keramik asing (guci bermotif telinga 4 guci, botol abad 9-10 $M$, piring kecil seladon dynasti
Ming abad ke 18-20 M, Mangkok (Ming abad ke 16-20 M), mangkok Ming, Mangkok Jepang 16 Masehi, Basi Eropa 16 M, Piring Mentega tahun 13 M)

b. Koleksi botol asing (guci bermotif 3 ikan abad $16 \mathrm{M}$, botol Cina abad ke $17 \mathrm{M}$, wadah tertutup dari Eropa abad 18-19 M, Mangkok bermotif biru dari Eropa abad $13 \mathrm{M})$

c. Keramik asing (Buli-buli dari Ming, cepik bagian bawah Dinasti Ming, tutup mangkok dari Dinsti Ching, lepek dari Eropa, Mangkok Ching)

d. Guci, terkota, kendi, piring, patung arca

- Artefak dari situs Sunan Bonang: Kayu berukir kalpartaru, Gentong, Wajan, Tempayan, Gentong batu, Mimbar, Brankas, Al Qur'an, Rekal, Tasbih biji pisang, Gapyak, Yoni, Nisan, Mamer lantai, Saka, ukiran kayu, bak air, foto makam sunan boning

- Rak kantor: Guci telinga 4, Guci motif, Pasu, Frafmen yoni, DII 
- Koleksi luar gedung: Kerangkeng, Meriam, Bak air, Prasasti, Jangkar, Pilar candi, Altar

Berdasarkan data di atas yang mengandung unsur perkembangan sejarah Islam di Indonesia secara umum dan kabupaten Tuban secara khusus adalah benda-benda artefak yang berasal dari kompleks Makam Sunan Bonang dan benda-benda lainnya yang dibuat pada tahun 1700-1800an.

\section{KESIMPULAN}

Pengelola Museum Kambang Putih telah melakukan penambahan koleksi, melakukan renovasi guna meningkatkan pelayanan terhadap pengunjung, $\mathrm{Hal}$ ini terbukti efektif untuk menarik pengunjung karena kondisi museum yang sudah lebih nyaman untuk dikunjungi. Moseum Kambang Putih memiliki daya tarik yang sangat potensial di daerah tuban, moseum kambang putih juga merupakan pemasok pemasukan daerah.

Saran yang penulis berikan adalah Perlunya kerjasama antara pemerintah, pihak pengelola objek daya tarik wisata dan masyarakat untuk mengembangan tempat wisata.Daerah tuban juga sudah membenahi diri dengan diaakanya atau dibentuknya Duta Priwisata Kabupaten Tuban, duta pariwisata disini memiliki tugas utama untuk mempromosikan kekayaan / potensi pariwisata di daerah Tuban.

\section{DAFTAR RUJUKAN}

Depdiknas. 2004. "Pedoman Merancang Sumber Belajar". Jakarta.

Dinas Kebudayaan dan Pariwisata Provinsi Jatim. "Museum Kambang Putih Tuban". Surabaya: Dinas Kebudayaan dan Pariwisata Provinsi Jatim.

Direktorat Permuseuman. 1999/2000. "Kecil Tapi Indah: Pedoman Pendirian Museum". Jakarta: Proyek Pendirian Permuseuman Jakarta, Ditjenbud, Depdikbud.

Agung. 2012. "Ongkek Yang Langka Di Museum Kambang Putih". Diupload pada Jum'at 21 Desember 2012. http://jelajah-nesia.blogspot.com /2012/12/jejak-budaya-ongkek-dimuseum-kambang.html. [diakses pada tanggal 5 februari 2013].

Museum Kambang Putih. 2014. "Grup FB Museum Kambang Putih". https://www.facebook.com/groups/29 1730464268889/ .[diakses pada tanggal 22 januari 2015] 